\title{
MERSEBURG PARS PRO TOTO: NAME, ETYMOLOGY AND MEANING IN THE CONTEXT OF THE MIDDLE AGES
}

Keywords: toponymy, toponomastics, ancient roots, potential of the place, GermanSlavonic contact zone

\begin{abstract}
Place-name research seems to be dominated by etymological questions. But other perspectives are important as well, as is demonstrated in one particular case: the conviction Thietmar of Merseburg manifests in his chronicle in the early $11^{\text {th }}$ century that the place of his bishopric seat was named after Mars, the Roman god of war. This was not just his personal belief, but rather it fully corresponds with the then prevailing beliefs used in explaining the world and names at that time. And, seemingly, this prominent etymology raised the importance and prestige of the place and its imperial palace, as it is outlined in the present article. ${ }^{1}$
\end{abstract}

From outside, onomastics often seems to be etymological research on proper names. Most notably are dictionaries explaining toponyms of a certain area, ${ }^{2}$ or giving parents help when naming their newborns by presenting them the "meaning" of various first names (e.g. Kohlheim, Kohlheim 2016; Meškank 2017). But onomastics is much more and comprises all aspects of the role the phenomenon of the "proper name" plays in language and society. Among these aspects, the theoretical character of the meaning of proper names has been a topic of discussion up to now. This discussion is too complex to be reduced to just one remark within the present

The author thanks Amanda Treppmann for improving the English of the present article.

2 See e.g. NMP; BNB; Foster, Willich (2007); for the former area of Old Sorbian the literature listed in Walther (2004: 115-123). Since then Hengst (2003), Eichler, Walther (2010), Eichler, Zschieschang (2011). Because of the huge amount of literature there can be given here and in the following titles only as examples. 
article. But it is sighted here to highlight that the meaning of a name is not just the meaning of the lexeme it was generated from. In fact, the specific "proprial meaning" proper names must be differentiated from their synonymous appellatives (Šrámek 2007a; Šrámek 2007b - in Czech language Šrámek 2016). This idea is not a new one, but well known (see e.g. Windberger-Heidenkummer 2017: 651 and already Freydank 1971: 2).

So, etymology is only a fundamental element of onomastic analysis, but a very important and necessary one. The dominance it has in the onomastic literature results from the huge amount of work which is necessary to clarify the etymology of the names, especially the extensive search in historic sources to find written mentions which illustrate the linguistic development of the names.

Onomastic analysis can only be reliable after such detailed etymological research is conducted. There are many fields of such linguistic and extra-linguistic analysis. E.g. the phonological development of place-names enriches research on the historical grammar of languages (Schaarschmidt 1998). Onomastics also contributes to the examination of language-contact (cf. Popowska-Taborska 1965 as a fundamental case study; basically e.g. Eichler 1976; Debus 1993; Nicolaisen 1996; Hengst et al. 1997; Stellmacher 2004; Hengst 2014). A further field is reconstruction of settlement development by the analysis of place-names. For many regions geographic investigations were conducted on the basis of a relative chronological differentiation between certain types of place-names to identify early-settled areas (Šmilauer 2015/1960; Eichler, Walther 1967: 175-195; Eichler, Walther 1970; Eichler, Walther 1984: 100-104; Eichler, Zschieschang 2011: 76-80; recently with a theoretical approach Zschieschang 2017: 75-86, 154-168).

In cases where there isn't one satisfying explanation for a name, discussions about etymological questions remain on-going. Although those discussion can easily dominate onomastic literature, it shouldn't be overlooked that they concern only a minority of names. E.g. a controversy about place-names in Lower and Upper Lusatia some years ago was dedicated to only ten percent of all toponyms in the region, while the explanations of the overwhelming 90 percent are clear and have not provided any reason for discussion (Zschieschang 2014: 522-523).

But, of course, there are the "difficult" names with several etymological theories and proposals, which necessarily must be discussed amongst onomastic scholars. Actually, there was such discussion about Merseburg, the name of a city at the Saale River on the Western Periphery of the historical Slavic language area, known from the famous Zaubersprüche (Merseburg charms/incantations; cf. Beck, Cottin 2015 as a brief introduction). Since publication of the regional place-name dictionary in the 1980 os there were four primary possible explanations of the name (Eichler, Walther 1984: 219; Hartig 2012: 406).

But, in the last few years some other proposals have appeared. Most convincing seems a derivation from $G{ }^{*}$ mersō 'gravel' (Bichlmeier 2015: 23-27; Bichlmeier 2016) according to the landscape: Exactly here, above the river valley of the Saale and the higher terrace is situated a narrow strip of gravel (Bichlmeier 2016: 27-29; GSK 4637), which would be a distinctive motivation for the naming of the 
place. But this explanation was doubted, and instead preferred $\mathrm{G}{ }^{\star}$ Marsi- (Casemir, Udolph 2017: 142). Another hypothesis refers to ${ }^{*}$ mars 'highly situated secure position' (Hengst 2015b: 447f.; Hengst 2016: 64-66). But this etymon is a naval term and obviously of Romanic origin (Etymologiebank). ${ }^{3}$ So, it is questionable whether it could be the origin of a place name far in the Central European inland already in the Early Middle Ages or before.

The question is whether such etymological discussions are actually fruitful. Of course, the exact determination of the elements in the single names is the essential fundament of onomastics. But, in many "difficult" cases, it is clear that one distinct explanation without any alternative is hardly achievable, and it is rather a question of which of the several theories is most probable. On the other hand, the focus on etymology can inhibit the view of some other aspects of place-name history, as in the case of Merseburg.

A thousand years ago, Thietmar of Merseburg, the famous chronicler of the border region between Franks and Saxons on one side and the Slavs on the other, in his voluminous chronicle, gave his view on the etymology of the name of his seat: Et quia tunc fuit hec apta bellis et in omnibus semper triumphalis, antiquo more Martis signata est nomine (Chronik I, 2; Thietmar: 5). In another source this explanation is extended to the historic context:

Sed quoniam a flumine magno Reno usque ad fluvium Salam et ultra universa victricibus armis Marte prosperante domuerat, hanc urbem bellis aptam deo Marti, quem praecipue colebat dicavit ac nomine consecravit eamque Marsburg, i. e. Martis urbem, appellavit. (Chronica episcoporum: 164; Rademacher 1903: 14)

From the view of current linguistics, this etymology is, of course, nonsense. ${ }^{4}$ There are no direct Latin or Italic influences on medieval place-names in the North of Central Europe. ${ }^{5}$ But, in the $11^{\text {th }}$ century, looking for those influences was the height of linguistic research. Bishop Thietmar, as a well-educated cleric, belonged to the intellectual elites during a time when the origin of toponyms was determined on the basis of the contemporary names (in written or orally used form) without considering its diachronic development. Furthermore, it was common opinion that this kind of etymology is closely connected to the named object, and that this connection has its origin in God's creation of the world (cf. Haubrichs 1995). In this context, Thietmar's explanation had during his lifetime the same status as the above mentioned current etymological thesis of present scientists has today. That is why recipients of his Latin etymology of Merseburg in the $11^{\text {th }}$ century believed it without any question. Moreover, for the ruling elites, it was a very attractive theory, as this reference to

This reference was given already in Zschieschang (2016a: 110, n. 62), Zschieschang (2016b: 215, n. 19).

4 About Thietmar's explanation cf. Hengst (2015a: 452-455), but without the conclusions stated in the present article.

5 A different aspect is the reinterpretation of names by humanistic scholars, as an example see former Boldewinsluch or Boldenstorff near Wittenberg, which in the $16^{\text {th }}$ century was re-semantized into Apollensdorf under humanistic influences by university scholars (Bergmann 1981). 
ancient history raised the importance of the place. A settlement with such prominent roots should be an important one, and because of this outstanding history it was considered dignified enough to host important persons, especially as a residence for the king or emperor (Zschieschang 2016a; Zschieschang 2016b). Even in the wider surrounding area there was no other castle erected by the Roman god of war.

In the $10^{\text {th }}$ and $11^{\text {th }}$ centuries Merseburg was indeed one of the favourite seats of the Ottonian kings and emperors (Schlesinger 1963: 174-180; Ehlers 2005: 12). Furthermore, it was the place where important guests were welcomed, such as the Polish king Bolesław Chrobry in 1013 (Regesten 3: 315-317, No. 463-465). There is no explicit evidence that it was mainly the place-name which led to the preference of Merseburg, but that such a name belonged to the 'potential of the place' (Ehlers 2005: 14) can hardly be doubted.

Regarding the importance of proper names for medieval history, it isn't only their etymology which is important. How medieval people interpreted the names themselves can also be instructive when attempting to better understand the human societies of that time.

\section{References}

Beck W., Cottin M. 2015. Die Merseburger Zaubersprüche. Eine Einführung. [= Kleine Schriften der vereinigten Domstifter zu Merseburg und Naumburg und des Kollegiatstifts Zeitz 8; $2^{\text {nd }}$ edition]. Petersberg.

Bergmann L. 1981. Zum Wandel des ON Pollensdorf in Apollensdorf. - Namenkundliche Informationen 39: 28-32. [available soon at: https://www.namenkundliche-informationen.de].

Bichlmeier H. 2015. Einige Anmerkungen zum Ortsnamen Merseburg. - Namenkundliche Informationen 105/106: 419-441. [available at: https://www.namenkundliche-informationen.de/baende/inhalt/30786/; accessed 2019-03-27].

Bichlmeier H. 2016. Indogermanistische Annäherungen an den Ortsnamen Merseburg. Bichlmeier H. (ed.). Germanen, Mars und Schotter. Das Geheimnis des Namens Merseburg. Hamburg: 9-39.

$B N B=$ Fischer R.E., Schlimpert G., Wauer S., Willich C., Foster E. 1967-2005. Brandenburgisches Namenbuch. [1-11 vols] Weimar; [vol. 12] Stuttgart.

Casemir K., Udolph J. 2017. Zum Ortsnamen Merseburg. - Namenkundliche Informationen 109/110: 108-146. [available soon at: https://www.namenkundliche-informationen.de].

Chronica episcoporum = Wilmans R. (ed.). 1852. Chronica episcoporum ecclesiae Merseburgensis. - Annales et chronica aevi Salici. Vita aevi Carolini et Saxonici. [= Monumenta Germaniae Historica. Scriptores 10]. Hannover: 157-212.

Chronik = Holtzmann R. (ed.). 1935. Die Chronik des Bischofs Thietmar von Merseburg und ihre Korveier Überarbeitung. [= Monumenta Germaniae Historica. Scriptores rerum Germanicarum, Nova series 9]. Berlin.

Debus F. (ed.). 1993. Deutsch-Slawischer Sprachkontakt im Lichte der Ortsnamen. Mit besonderer Berücksichtigung des Wendlandes. [= Kieler Beiträge zur deutschen Sprachgeschichte 15]. Neumünster.

Ehlers C. 2005. Merseburg als Ort der ostfränkisch-deutschen Könige. - Kunde H., Ranft A., Sames A., Wittmann H. (eds.). Zwischen Kathedrale und Welt. 1000 Jahre Domkapitel 
Merseburg. Aufsätze. [= Schriftenreihe der Vereinigten Domstifter zu Merseburg und Naumburg und des Kollegiatstifts Zeitz 2]. Petersberg: 9-18.

Eichler E. 1976. Sprachkontakte im Lichte der Onomastik. - Onoma 20: 128-141.

Eichler E., Walther H. 1967. Die Ortsnamen im Gau Daleminze. II. Namen- und Siedlungskunde. [= Deutsch-Slawische Forschungen zur Namenkunde und Siedlungsgeschichte 21]. Berlin.

Eichler E., Walther H. 1970. Ortsnamen und Besiedlungsgang in der Altlandschaft Nisane im frühen Mittelalter. - Fischer R., Eichler E. (eds.). Beiträge zum Slawischen Onomastischen Atlas. Theodor Frings zum Gedächtnis. [= Abhandlungen der Sächsischen Akademie der Wissenschaften zu Leipzig, Philologisch-historische Klasse 61/2 A]. Berlin: 75-90.

Eichler E., Walther H. 1984. Untersuchungen zur Ortsnamenkunde und Sprach- und Siedlungsgeschichte des Gebietes zwischen mittlerer Saale und weißer Elster. [= Deutsch-Slawische Forschungen zur Namenkunde und Siedlungsgeschichte 35]. Berlin.

Eichler E., Walther H. 2010. Alt-Leipzig und das Leipziger Land. Ein historisch-geographisches Namenbuch. [= Onomastica Lipsiensia 7]. Leipzig.

Eichler E., Zschieschang Ch. 2011. Die Ortsnamen der Niederlausitz östlich der Neiße. [= Abhandlungen der Sächsischen Akademie der Wissenschaften zu Leipzig, Philologisch-historische Klasse 81.6]. Stuttgart, Leipzig.

Etymologiebank = van der Sijs N. (ed.). Etymologiebank. [http://www.etymologiebank.nl/ trefwoord/mars2; accessed 2019-03-27].

Foster E., Willich C. 2007. Ortsnamen und Siedlungsentwicklung. Das nördliche Mecklenburg im Früh- und Hochmittelalter. [= Forschungen zur Geschichte und Kultur des östlichen Mitteleuropas 31]. Stuttgart.

Freydank D. 1971. Ortsnamenkunde als philologische Disziplin. -Witkowski T. (ed.). Forschungen zur slawischen und deutschen Namenkunde. [= Deutsche Akademie der Wissenschaften zu Berlin. Veröffentlichungen des Instituts für Slawistik 55]. Berlin: 1-7.

GSK 4637 = Königlich Preußische Geologische Landesanstalt (ed.). 1909. Geologische Karte von Preußen und benachbarten Bundesstaaten [Lieferung 52, Blatt 4637]. Merseburg (West), Berlin.

Hartig M. 2012. Merseburg. - Niemeyer M. (ed.). Deutsches Ortsnamenbuch. Berlin, Boston: 406.

Haubrichs T. 1995. Namendeutung im europäischen Mittelalter. - Eichler E., Hilty G., Löffler H., Steger H., Zgusta L. (eds.). Namenforschung. Ein internationales Handbuch zur Onomastik. [= vol. 1: Handbücher zur Sprach- und Kommunikationswissenschaft 11.1]. Berlin, New York: 351-360.

Hengst K. 2003. Ortsnamen Südwestsachsens. Die Ortsnamen der Kreise Chemnitzer Land und Stollberg. [= Deutsch-Slawische Forschungen zur Namenkunde und Siedlungsgeschichte 39]. Berlin.

Hengst K. 2014. [Ernst P. (ed.)]. Sprachkontakte, Sprachstudien und Entlehnungen im östlichen Mitteldeutschland seit einem Jahrtausend. Ausgewählte Studien zur Sprach- und Namenforschung. [= Schriften zur diachronen Sprachwissenschaft 21]. Wien.

Hengst K. 2015a. Der Ortsname Merseburg. - Cottin M., Filip V.V., Kunde H. (eds.). 1000 Jahre Kaiserdom Merseburg. Ausstellungskatalog. [= Schriftenreihe der Vereinigten Domstifter zu Merseburg und Naumburg und des Kollegiatstifts Zeitz 9]. Petersberg: 188-190.

Hengst K. 2015b. Der Ortsname Merseburg und sein Geheimnis. - Namenkundliche Informationen 105/106: 442-459. [available at: https://www.namenkundliche-informationen. de/baende/inhalt/30786/; accessed 2019-03-27].

Hengst K. 2016. Merseburg - ,Utkiek'? - Bichlmeier H. (ed.). Germanen, Mars und Schotter. Das Geheimnis des Namens. Merseburg, Hamburg: 41-83. 
Hengst K., Krüger D., Walther H. (eds.). 1997. Wort und Name im deutsch-slavischen Sprachkontakt. Ernst Eichler von seinen Schülern und Freunden. [= Bausteine zur slavischen Philologie und Kulturgeschichte N.F. 20]. Köln, Weimar, Wien.

Kohlheim R., Kohlheim V. 2016. Duden. Das große Vornamenlexikon. [5 ${ }^{\text {th }}$ edition]. Berlin.

Meškank T. 2017. Serbske předmjena / Serbske pśedmjenja / Sorbische/wendische Vornamen. Budyšin.

Nicolaisen W.F.H. 1996. Language contact and onomastics. - Goebl H., Nelde P.H., Starý Zd., Wölck W. (eds.). Kontaktlinguistik. Ein internationales Handbuch zeitgenössischer Forschung. [= vol. 1: Handbücher zur Sprach- und Kommunikationswissenschaft 12.1]. Berlin, New York: 549-554.

$N M P=$ Rymut K., Czopek-Kopciuch B., Bijak U. (eds.). 1996-. Nazwy miejscowe Polski. Historia - pochodzenie - zmiany. [until now 14 vols.]. Kraków. [available at: http://rcin. org.pl/ijp/publication/15454; accessed ED 2019-03-27].

Popowska-Taborska H. 1965. Dawne pogranicze językowe polsko-dolnołużyckie (w świetle danych toponomastycznych). [= Prace Językoznawcze 44]. Wrocław, Warszawa, Kraków.

Rademacher O. 1903. Die Merseburger Bischofschronik. Übersetzt und mit Anmerkungen versehen. Teil I (bis 1136). Merseburg.

Regesten = Lübke Ch. 1984-1988. Regesten zur Geschichte der Slaven an Elbe und Oder (vom Jahr 900 an). [5 vols.]. Berlin.

Schaarschmidt G. 1998. A historical phonology of the upper and lower Sorbian languages. [= Historical phonology of the Slavic languages 6]. Heidelberg.

Schlesinger W. 1963. Merseburg (Versuch eines Modells künftiger Pfalzbearbeitungen). Gauert. A. (ed.). Deutsche Königspfalzen. Beiträge zu ihrer historischen und archäologischen Erforschung 1. [= Veröffentlichungen des Max-Planck-Instituts für Geschichte 11.1]. Göttingen: 158-206.

Šmilauer V. 2015/1960. Osídlení Čech ve světle místních jmen. [ $1^{\text {st }}$ edition 1960]. Praha.

Šrámek R. 2007a. Etymologie und Deutung in der Namenkunde. - Šrámek R. [Hansack E. (ed.)]. Beiträge zur allgemeinen Namentheorie. Wien: 45-63. [Originally in: Brendler A., Brendler S. (ed.). 2004. Namenarten und ihre Erforschung. Hamburg: 93-106].

Šrámek R. 2007b. Zur Grenze zwischen Namenkunde und Etymologie. - Šrámek R. [Hansack E. (ed.)]. Beiträge zur allgemeinen Namentheorie. Wien: 40-44. [Originally in Nicolaisen W.F.H. (ed.). 1998. Proceedings of the XIXth International Congress of Onomastic Sciences. Aberdeen August 4-11, 1996 "Scope, perspectives and methods of onomastics"; vol. 1; Aberdeen: 325-329].

Šrámek R. 2016. Anoikonymické objekty a jejich pojmenování. - Šrámek R. Labyrintem vlastních jmen a nářečí. [= Studie osobností brněnské lingvistiky 6]. Brno: 193-199. [Originally in: Nicolaisen W.F.H. (ed.). 1998. Proceedings of the XIXth International Congress of Onomastic Sciences. Aberdeen August 4-11, 1996 "Scope, perspectives and methods of onomastics'; vol. 1; Aberdeen: 325-329].

Stellmacher D. (ed.). 2004. Sprachkontakte. Niederländisch, Deutsch und Slawisch östlich von Elbe und Saale. [= Wittenberger Beiträge zur deutschen Sprache und Kultur 3]. Frankfurt am Main.

Thietmar = Trillmich W. (ed.). 1957. Thietmar von Merseburg: Chronik. Neu übertragen und erläutert. [= Ausgewählte Quellen zur deutschen Geschichte des Mittelalters. Freiherrvom-Stein-Gedächtnisausgabe 9]. Darmstadt.

Walther H. 2004. [Eichler E., Hengst K., Udolph J. (eds.)]. Namenkunde und geschichtliche Landeskunde. Ein einführender Überblick, Erläuterungen namenkundlicher Fachbegriffe. Auswahlbibliographie zur Namenkunde und Landeskunde Ostmitteldeutschlands. [= Onomastica Lipsiensia 1]. Leipzig. 
Windberger-Heidenkummer E. 2017. Zwischen linguistischen Welten: Onymische Phraseme als Phraseologismen und Eigennamen. - Namenkundliche Informationen 109/110: 522-544. [available soon at: https://www.namenkundliche-informationen.de].

Zschieschang C. 2014. Die Neißeprovinz als Kleingau? Eine Erwiderung zum Beitrag von Walter Wenzel über „Die provincia Nice“. - Namenkundliche Informationen 103/104: 522-544. [available at: https://www.namenkundliche-informationen.de/baende/inhalt/ 13427/; accessed 2019-03-27].

Zschieschang C. 2016a. Die Bedeutung Merseburgs im frühen und hohen Mittelalter. Bichlmeier H. (ed.). Germanen, Mars und Schotter. Das Geheimnis des Namens Merseburg. Hamburg: 85-120.

Zschieschang C. 2016b. Merseburg. Zur 'Bedeutung' des Namens. - Hough C., Izdebska D. (eds.). Names and Their Environment. Proceedings of the 25th International Congress of Onomastic Sciences, Glasgow, 25-29 August 2014. [vol. 2: Toponomastics 2]. Glasgow: 206-219.

Zschieschang C. 2017. Das Hersfelder Zehntverzeichnis und die frühmittelalterliche Grenzsituation an der mittleren Saale. Eine namenkundliche Studie. [= Forschungen zur Geschichte und Kultur des östlichen Mitteleuropa 52]. Köln, Weimar, Wien. 
